DOI: http://doi.org/10.15688/nav.jvolsu.2018.1.1

UDC 903'1:008(470.45)

LBC 63.442(2P-4Bог)-7

\title{
ON THE SUCCESSION OF SARMATIAN CULTURES AND POPULATION (BASED ON THE MATERIALS OF THE KALINOVSKY BURIAL MOUND) ${ }^{1}$
}

\author{
Mariya A. Balabanova \\ Volgograd State University, Volgograd, Russian Federation \\ Anatoliy S. Skripkin \\ Volgograd State University, Volgograd, Russian Federation
}

\begin{abstract}
The paper presents the results of a new research into the archaeological and anthropological materials of the Kalinovka burial mound of the Sarmatian time. For the first time, these materials were investigated by V.P. Shilov and V.V. Ginzburg in 1959. On the basis of modern developments in archaeology of Sarmatian antiquities and achievements of Russian and foreign anthropology, we present a fairly objective picture of the interaction of local and foreign components of this site. Conservation of some elements of the funeral ceremony in the Early and Middle Sarmatian times, the foundation of burial cemeteries without disturbing the graves of predecessors, as well as the similarity of morphological type of these chronological groups allows concluding that the members of one paleopopulation, possibly including a small number of "foreigners", were buried in the studied burial mound. The research results based on different methods, including the method of multidimensional statistics, show that the materials of the Late Sarmatian time are completely different from those of the Early and Middle Sarmatian times.
\end{abstract}

Key words: The Lower Volga region, Kalinovsky burial mound, Sarmatians, chronology, anthropological type, succession, innovations.

Citation. Balabanova M.A., Skripkin A.S., 2018. On the Succession of Sarmatian Cultures and Population (Based on the Materials of the Kalinovsky Burial Mound). The Lower Volga Archaeological Bulletin, vol. 17, no. 1, pp. 5-26. (in Russian).

УДК 903'1:008(470.45)

ББК 63.442(2P-4Вог)-7

\section{О ПРЕЕМСТВЕННОСТИ САРМАТСКИХ КУЛЬТУР И НАСЕЛЕНИЯ (ПО МАТЕРИАЛАМ КАЛИНОВСКОГО КУРГАННОГО МОГИЛЬНИКА) ${ }^{1}$}

\author{
Мария Афанасьевна Балабанова
}

Волгоградский государственный университет, г. Волгоград, Российская Федерация

Анатолий Степанович Скрипкин

Волгоградский государственный университет, г. Волгоград, Российская Федерация

Аннотация. В статье приводятся результаты нового исследования археологических и антропологических материалов сарматского времени могильника Калиновка, впервые опубликованных В.П. Шиловым и 
В.В. Гинзбургом в 1959 году. На основе современных разработок в археологии сарматских древностей и достижений российской и зарубежной антропологии проводилось сопоставление археологических и антропологических материалов, которое позволило предложить достаточно объективную картину взаимодействия местного и пришлого компонентов данного памятника. Сохранение отдельных элементов погребального обряда раннесарматского и среднесарматского времени, практика курганов-кладбищ не нарушать могил предшественников, а также сходство морфологического типа этих хронологических групп позволяет утверждать, что в могильнике были погребены члены одной палеопопуляции, возможно, с включением незначительного количества «инородцев». Материал позднесарматского времени резко отличается от материалов раннесарматского и среднесарматского времени как по археологическому комплексу, так и по антропологическому типу, что демонстрируют результаты различных уровней исследования, в том числе и методы многомерной статистики.

Ключевые слова: Нижнее Поволжье, Калиновский курганный могильник, сарматы, хронология, антропологический тип, преемственность, новации.

Цитирование. Балабанова М. А., Скрипкин А. С., 2018. О преемственности сарматских культур и населения (по материалам Калиновского курганного могильника) // Нижневолжский археологический вестник. T. 17, № 1. C. 5-26.

\section{Введение}

Усилиями основателей сарматской археологии к середине XX в. была разработана археологическая периодизация сарматских древностей, включающая три хронологически последовательные культуры: раннюю, среднюю и позднюю. Практически эта периодизационная схема сохраняется и в настоящее время. Последующие исследователи вносили уточнения в отношении датировок отдельных культур этой периодизации, выделяли новые элементы в их материальной культуре и погребальном обряде, пытались выяснить этническую принадлежность каждой из названных культур. Одной из остро обсуждаемых была проблема происхождения этих культур, выявления механизмов их формирования. Диапазон мнений по этой проблеме был достаточно широк, от утверждения ведущей роли автохтонных процессов в их формировании до миграционного их происхождения.

Обычно проблема преемственности сарматских культур рассматривалась с учетом погребальных комплексов из разных курганных могильников в пределах больших регионов, таких как Нижнее Поволжье, Нижний Дон или Северное Причерноморье. Однако при таком подходе теряются отдельные нюансы, имеющие важное значение для решения данной проблемы. Обычно во многих случаях в курганных могильниках от Южного Урала до Северного Причерноморья находятся погребения, относящиеся к разным сарматским культурам. Важным в плане решения вопроса о преемственности этих культур является выяснение: оставлены ли погребения разных сарматских культур одной популяцией населения и данный могильник в течение длительного времени использовался как родовое кладбище или со сменой культур происходит смена населения и старый могильник продолжает использоваться новым населением.

Подход, который может быть использован в выяснении изложенной ситуации, должен основываться на анализе погребального обряда, который позволит выяснить: происходят какие-то существенные его изменения или обряд сохраняет основные свои характеристики, а изменения затрагивают только материальную культуру. Существенным дополнением в решении рассматриваемой проблемы будет анализ антропологического материала, происходящего из погребальных сарматских комплексов изучаемого могильника.

\section{Анализ археологического материала могильника}

В качестве примера мы взяли Калиновский курганный могильник, исследованный в 50-е гг. прошедшего века экспедицией под руководством В.П. Шилова [Шилов, 1959, с. 323-523]. Могильник располагался на левом берегу Волги в пределах теперешней Волгоградской области. За три полевых сезона (1952-1954 гг.) экспедицией в могильнике было раскопано 62 кургана, в которых обна- 
ружено 253 погребения, датируемых в диапазоне от эпохи бронзы до средневековья включительно. Значительное их количество относилось к раннему железному веку и датировалось сарматским временем. По определению В.П. Шилова, по культурам они распределяются следующим образом: раннесарматская - 64 комплекса; среднесарматская - 60; позднесарматская - 31 .

В датировках сарматских погребений Калиновского курганного могильника В.П. Шилов исходил из представления своего времени, сформированного к середине прошлого века. Погребения могильника, относимые к раннесарматской культуре, он датировал IV-II вв. до н.э., среднесарматские - I в. до н.э. - I в. н.э., позднесарматские - II-IV вв. н.э.

Ознакомление с погребальными комплексами, относимыми В.П. Шиловым к раннесарматскому времени, показывает, что большая их часть, в которых содержится материал, позволяющий высказаться о времени их сооружения, являются наиболее поздними в рамках раннесарматской культуры. Их следует относить ко II-I вв. до н.э. Так, в десяти раннесарматских погребениях найдены наконечники стрел, в ряде случаев они представляют колчанные наборы. Все они оказались железными черешковыми с трехлопастной головкой. В пяти случаях они найдены вместе с мечами или кинжалами, имеющими прямое перекрестие и серповидное навершие. Такое сочетание предметов вооружения в сарматских погребениях характерно для II-I вв. до н.э., поскольку в сарматских погребениях IV в. до н.э. в колчанах преобладают бронзовые втульчатые наконечники, а для III в. до н.э. характерно сочетание бронзовых и железных наконечников стрел [Клепиков, Скрипкин, 2002, с. 47-81]. В некоторой степени дату раннесарматских погребений Калиновского могильника подтверждает находка фибулы среднелатенской схемы со скрепленной ножкой в погребении 3 кургана 27 [Шилов, 1959, с. 384, рис. 41,1]. Фибулы такой конструкции датируются второй половиной или последней четвертью II І в. до н.э. [Кропотов, 2010, с. 44].

В.П. Шилов предложил датировать раннесарматское погребение 17 из кургана 19 более ранним временем на основании нахож- дения в нем длинного меча прохоровского типа и фрагмента бронзового зеркала с плоской ручкой, найдя им аналогии в памятниках IVIII вв. до н.э. [Шилов, 1959, с. 432-434]. Однако аналогии эти во многом случайные, поскольку мечи и зеркала этих типов могли существовать более длительное время. Например, длинные мечи с прямым перекрестием и серповидным навершием известны в сарматских погребениях вплоть до I в. до н.э. В указанном погребении кургана 19 были обнаружены длинный меч совместно с такого же типа кинжалом и железными наконечниками стрел. Совместные находки мечей и кинжалов с серповидными навершиями в сарматских погребениях известны в III в. до н.э., но в этом случае находящиеся с ними колчанные наборы стрел обычно состояли из бронзовых и железных наконечников [Скрипкин, 2015, с. 191-197]. Нахождение с таким набором клинкового оружия исключительно железных наконечников стрел указывает на более позднюю дату этого погребального комплекca. В этом отношении более объективной аналогией погребению из 19 калиновского кургана могут быть находки из погребения 3 Быковского кургана 2, находившегося также в Волгоградском Заволжье и раскопанного в 1977 г. экспедицией Волгоградского педагогического института. В нем также находились меч и кинжал с серповидными навершиями и железные трехлопастные черешковые наконечники стрел, кроме того, здесь же была найдена бронзовая фрагментированная среднелатенская фибула, позволяющая более уверенно датировать этот комплекс, а вместе с ним и калиновский, II-I вв. до н.э. [Скрипкин,1990а, с. 106, 107].

Да и другие находки вещей свидетельствуют о принадлежности погребений, отнесенных В.П. Шиловым к раннесарматской культуре, к заключительному ее этапу. Это наличие в погребениях фрагментов бронзовых зеркал с валиком по краю диска, что наиболее типично для позднепрохоровских погребальных комплексов. В более ранних погребениях этой культуры обычно встречаются целые зеркала. В целом о позднем возрасте в рамках прохоровской культуры свидетельствует наличие в погребениях могильника лепных горшков с выраженным туловом, невысоким 
горлом, украшенных по тулову вертикальными пучками линий.

Принадлежность рассматриваемых комплексов к раннесарматской культуре подтверждается не только типичными для нее типами вещей, но и наличием, например, достаточно большого количества детских погребений, 26,6 \% ${ }^{2}$ от всей выборки раннесарматских захоронений. Вероятно, их было больше, поскольку в общую выборку не вошли и полностью ограбленные погребения. В среднесарматской культуре детские погребения встречаются реже и еще реже в позднесарматское время.

Обратимся теперь к тем погребениям Калиновского курганного могильника, которые В.П. Шилов датировал I в. до н.э. - I в. н.э., отнеся их к среднесарматской культуре. Сначала рассмотрим их с позиции хронологии. Обратимся к вещевому материалу. Следует отметить, что по сравнению с рассмотренными выше калиновскими более ранними комплексами, в этой хронологической группе появляются новые типы вещей: мечи с кольцевым навершием [Шилов, 1959, рис. 49,1,5-9, 59,2,6], бронзовые плоские зеркала без ручек и зеркала с валиком по краю и умбоном в центре диска [Шилов, 1959, рис. 52,2,9-14,18], увеличивается разнообразие глиняной посуды, изготовленной на гончарном круге [Шилов, 1959, рис. 54, 55].

Мечи и кинжалы с кольцевым навершием действительно являются наиболее распространенным типом клинкового оружия в погребениях среднесарматской культуры, но периодически они начинают употребляться еще на заключительном этапе раннесарматской культуры, встречаясь в одних комплексах с мечами и кинжалами с серповидным навершием [Скрипкин, 2005, с. 182, 183].

Бронзовые зеркала, которые обнаружены в сарматских погребениях в виде плоских дисков, в свое время А.С. Скрипкин по размерному признаку разделил на два варианта: первый вариант - зеркала с диаметром диска 50-90 мм и второй вариант - зеркала диаметром 100-240 мм. В рассматриваемой выборке калиновских погребений большинство зеркал этого типа представлены первым вариантом. Проверка их на встречаемость с другими категориями вещей позволила дати- ровать эти зеркала в пределах I в. до н.э. I в. н.э., с преобладанием их в I в. н.э. [Скрипкин, 1990б, с. 153]. То же самое можно сказать и о зеркалах с валиком по краю диска и умбоном в его центре [Скрипкин, Минеева, 2004, с. 212-214].

В.П. Шилов, датируя данную группу погребений Калиновского могильника I в. до н.э. - I в. н.э., исходил из датировки этим временем среднесарматской, сусловской по Б.Н. Гракову, культуры, принятой в то время. В настоящее время сложившуюся среднесарматскую культуру датируют I в. н.э. - первой половиной II в. н.э. Исходя из новой даты среднесарматской культуры не все погребения Калиновского курганного могильника, определенные В.П. Шиловым как среднесарматские, относятся к этой культуре, поскольку, отдельные типы вещей из этих погребений начинают встречаться еще на заключительном этапе раннесарматской культуры. Об этом, в частности, свидетельствует датировка отдельных типов керамической посуды из погребений рассматриваемой группы. Так, например, кувшин из кургана 61, погребение 2 [Шилов, 1959, рис. 55,1], находит близкие аналогии среди керамической посуды Центрального Предкавказья в памятниках III-I вв. до н.э. [Абрамова, 1993, с. 40-44, рис. 8]. Аналогичные сосуды известны на Кубани в комплексах второй половины II в. до н.э. [Марченко, 1996, с. 87, рис. 76,2]. Кувшин из калиновского кургана 1, погребение 6 [Шилов, 1959, рис. $55,7]$, также, скорее всего, северокавказского происхождения. Кувшины такого типа известны на территории Кабардино-Балкарии в памятниках II-I вв. до н.э. [Керефов, 1988, рис. 13,1$]$.

Особый интерес представляет богатое женское погребение 8 из калиновского кургана 55, включенное автором раскопок в перечень среднесарматских погребений. В нем кроме золотых украшений найдены импортные бронзовые сосуды, стеклянная чаша, бронзовая лучковая подвязная фибула. По своим признакам фибула относится к самому раннему варианту этого типа. Находки раннего варианта лучковых фибул известны в памятниках заключительного этапа раннесарматской культуры [Сергацков, 2000, с. 161-170]. В.В. Кропотов, проанализировав всю совокупность нахо- 
док этого варианта фибул в Юго-Восточной Европе, предложил датировать их второй половиной или последней четвертью I в. до н.э. серединой I в. н.э. [Кропотов, 2010, с. 71, 72]. Скорее всего, сооружение погребения 8 из кургана 55 следует относить к рубежу эр. Это, в частности, подтверждается находкой одного из бронзовых кувшинов в погребении 8 , являющегося римским импортом [Шилов, 1959, рис. 57,3$]$, распространение такого типа сосудов приходится на последние десятилетия I в. до н.э. - первые десятилетия I в. н.э. [Raev, 1994, s. 349, 350].

Таким образом, в хронологическом отношении погребальные комплексы Калиновского курганного могильника, которые В.П. Шилов разделил по двум культурам, не ограничены строго теми хронологическими рамками, которые он указал для раннесарматских и среднесарматских погребений, по времени они накладывались друг на друга и сооружались непрерывно в промежутке со II в. до н.э. по І в. н.э. или середину II в. н.э.

Следует отметить, что обе группы погребений Калиновского могильника очень близки по погребальному обряду. Для среднесарматской культуры наиболее типичны основные погребения под курганной насыпью. Для территории Азиатской Сарматии этот показатель равен 57,45 \% [Сергацков, 2002, с. 89], в то время как для раннесарматской культуры той же территории основные погребения составляли 3,4 \% [Скрипкин, 1997, с. 179]. В Калиновском могильнике раннесарматские погребения были все впускными. Погребения Калиновского могильника, датированные В.П. Шиловым І в. до н.э. - І в. н.э. и относимые к среднесарматской культуре, также оказались в большинстве своем впускными в более древние курганы, основные же составили 13,3 \%. Таким образом, по этому показателю погребального обряда различия между двумя хронологическими пластами сарматских захоронений могильника, отождествляемые с разными культурами, невелики. Преобладание впускных погребений, датированных В.П. Шиловым I в. до н.э. - І в. н.э., сближает их в рамках одного могильника с более ранним пластом сарматских захоронений.

Значительное сходство эти две хронологически различные группы обнаруживают и по типам могильных ям. Наиболее распространенными у них являются могильные ямы простой прямоугольной формы, с разной вариацией по длине и ширине. Затем в меньшем количестве следуют подбойные ямы. Несущественные различия заключаются в наличии двух ям катакомбной конструкции в раннесарматских захоронениях (кург. 19, погр. 21; кург. 55, погр. 12) и двух подквадратных ям, являвшихся основными в курганах, в одном случае с диагональным положением погребенного (кург. 34), в другом, предположительно с таким же положением погребенного, поскольку в связи с ограблением это установить не удалось (кург. 41). Ориентировка в обеих хронологических группах погребений Калиновского могильника преобладает в южный сектор, с разными вариантами отклонений к востоку и западу. Практически одинаков процент детских захоронений, в среднесарматских погребениях он составляет $28,3 \%$, при 26,6 \% в раннесарматских погребениях того же могильника.

Одним из признаков близости населения, оставившего погребения, относящиеся к ранне- и среднесарматской культурам, является то, что значительная их часть обнаружена в одних и тех же курганах. Так, в кургане 3 к раннесарматскому времени относилось 9 погребений, к среднесарматскому - 7; в кургане 8 раннесарматских погребений - 14, среднесарматских - 12; в кургане 12 раннесарматских -12 , среднесарматских -9 .

Сохранение основных признаков погребального обряда раннесарматской культуры в среднесарматское время, сооружение большинства погребений обоих хронологических групп в одних и тех же курганах, вероятно, свидетельствует о том, что погребальные комплексы Калиновского курганного могильника последних веков до нашей эры и первых веков новой эры оставлены одной и той же популяцией сарматского населения. Изменениям подвергалась только материальная культура. В большинстве погребальных комплексов II-I вв. до н.э. могильника преобладали вещи, характерные для раннесарматской культуры (мечи и кинжалы с серповидным навершием, фрагменты зеркал с валиком по краю диска, лепные сосуды, украшенные по тулову пучками прочерченных вертикальных линий). 
В погребальных комплексах I - середины II в. н.э. того же могильника преимущественно распространяются вещи уже других типов (мечи и кинжалы с кольцевым навершием, бронзовые зеркала с плоским диском, зеркала с валиком по краю диска и умбоном в его центре, гончарная сероглиняная керамика, преимущественно кувшинных форм). Изменение типов вещей в данном случае не свидетельствует о каких-либо этнических изменениях, произошедших в данном районе Заволжья, оно может быть объяснено изменением моды на вещи материальной культуры, поскольку эта тенденция была характерна не только для данного могильника, она охватывала значительные степные пространства, освоенные сарматами.

Основные элементы погребального обряда претерпевают существенные изменения в погребальных комплексах позднесарматского времени Калиновского могильника. В.П. Шилов отнес к этому периоду 31 погребение, датировав их II-IV вв. н.э. Вопрос вызывают четыре погребения из этого перечня в отношении принадлежности их к позднесарматской культуре. В ограбленном погребении 2 из кургана 28 были обнаружены железные плоские наконечники стрел, что не характерно для всех сарматских культур, такого типа наконечники начинают распространяться с раннего средневековья. В кургане 43, погребение 1, которое оказалось ограбленным, были обнаружены зуб и копыто лошади, других вещей не найдено. Наличие костей ног лошади не характерно для сарматских погребений, эта деталь обряда широко распространяется в погребальной практике средневековых кочевников. Полностью разрушенное погребение 5 из кургана 54 было отнесено В.П. Шиловым на основании обнаруженного в нем лепного горшка, информативность которого может быть подвергнута сомнению. Из списка курганов, относящихся к позднесарматскому времени, следует исключить курган 25, в котором погребение не было обнаружено, но который В.П. Шилов на основании обнаружения в нем фрагмента узкогорлого сосуда (?) включил в список позднесарматских.

Вызывает сомнение и отнесение четыpex впускных детских захоронений (кург. 8, погр. 18; кург. 11, погр. 1; кург. 55, погр. 1, 4) к позднесарматской культуре. Вещевой материал в них невыразительный. Отнесены они были В.П. Шиловым к этой культуре, видимо, на основании ориентировки детских костяков в северный сектор.

Исключив четыре названных выше погребения (кург. 28, погр. 2; кург. 25; кург. 43, погр. 1; кург. 54, погр. 5) из списка позднесарматских и сохранив в нем указанные впускные детские погребения, будем в дальнейшем оперировать оставшимися 27 комплексами позднесарматского времени Калиновского могильника.

В.П. Шилов отмечал, что для позднесарматских погребений могильника характерно увеличение захоронений под небольшими индивидуальными насыпями. Этот фактор приводит к значительному возрастанию основных погребений в курганах по сравнению с предыдущими периодами. Таковых оказалось 21 захоронение (77,2 \%) из 27, с учетом четыpeх детских впускных захоронений. Из 23 случаев выявленных форм могильных ям, 12 являлись подбойными, 9 - удлиненными прямоугольными, 2 - подквадратными с диагональным положением костяков.

В 20 случаях была выявлена ориентировка погребенных, преобладающей является ориентировка в северный сектор (14 случаев) и в южный (6 случаев). Новым явилось распространение обычая искусственной деформации головы, которая была выявлена в 9 случаях (33,3 \%). Снижается количество детских захоронений по сравнению с предыдущими, хронологическими группами сарматских погребений могильника, с учетом указанных выше слабо документированных впускных детских захоронений, оно равно $18,5 \%$, без этих погребений в поздней группе известен только один случай захоронения ребенка с взрослой женщиной (кург. 39, погр. 1).

Происходят изменения и в материальной культуре населения, оставившего позднесарматские погребальные комплексы. Получают распространение мечи и кинжалы без металлических перекрестий и наверший, сложносоставной лук, о чем свидетельствуют находки костяных накладок, являющиеся деталями таких луков [Шилов, 1959, рис. 61]. В отдельных случаях обнаружены бронзовое зеркало с центральной петелькой [Шилов, 1959, 
рис. 62,16 , железные пружинные ножницы [Шилов, 1959, рис. 60,8], бронзовый флакончик [Шилов, 1959, рис. 62,18]. Значительно увеличивается количество находок фибул [Шилов, 1959, рис. 62, 2-5]. Все эти вещи наиболее типичны для позднесарматских комплексов второй половины II - первой половины III в. до н.э.

Среди вещей нет тех типов, которые позволили бы датировать некоторые комплексы в рамках поздней группы сарматских погребений Калиновского могильника IV в. н.э. Большинство погребений могильника, относимых к позднесарматской культуре, следует ограничить, видимо, временем с середины II по середину III в. н.э., некоторые, возможно, в рамках всего III в. н.э. Так, лучковые подвязные фибулы с внешней тетивой (кург. 13, погр. 1; кург. 7, погр. 1), относимые к 4 и 5 вариантам ранеепринятой их классификации, датируются преимущественно второй половиной II - первой половиной III в. н.э. [Скрипкин, 1977, c. 107]. В.В. Кропотов на массовом материале Юго-Восточной Европы убедительно доказал, что хронологических различий между двумя наиболее поздними вариантами лучковых подвязных фибул данного типа, выделенных в свое время А.К. Амброзом, не существует. Он объединил оба эти варианта в один вариант 4 своей классификации лучковых подвязных фибул с верхней тетивой. Согласуясь с другими исследователями, В.В. Кропотов датирует лучковые фибулы этого варианта заключительной частью II - первой половиной III в. н.э. Завершение распространения этого типа лучковых фибул он связывает с разгромом готами в середине III в. н.э. большинства производственных центров Северного Причерноморья и соответственно упадком их экономики, выходом из употребления почти всех ранее находившихся в обороте типов вещей [Кропотов, 2010, с. 80].

Еще одна лучковая фибула, но иной конструкции, была обнаружена в кургане 42, погребение 2. Это двучленная лучковая фибула с внутренней тетивой, проверить ее датировку на основании других вещей в погребении не представляется возможным, поскольку кроме фибулы здесь больше ничего не было обнаружено. В свое время один из авторов этой статьи высказался за датировку этого типа фибул второй половиной III в., подчеркнув, что эта дата пока справедлива для Нижнего Поволжья [Скрипкин, 1977, с. 108, 109]. Гораздо позже эта дата рассматриваемых фибул на более массовом материале была подтверждена В.В. Кропотовым [Кропотов, 2010, c. 154-157].

В кургане 20 в единственном погребении была найдена фибула с плоской коленоизогнутой спинкой и завитком на конце сплошного приемника. Фибулы такого типа широко распространены в позднесарматских памятниках Южного Приуралья. М.Г. Мошкова, возражая против поздней датировки фибул этого типа, предложенной А.К. Амброзом, с опорой на новые находки, посчитала возможным датировать их все III в., не исключая и вторую половину II в. н.э. [Мошкова, 2000, с. 190] Позже эта дата была уточнена В.Ю. Малашевым, который предложил фибулы этого типа датировать первой половиной III в. н.э. с последующим использованием их во второй его половине [Малашев, Яблонский, 2008, с. 62].

Значительные изменения в погребальной обрядности позднесарматских комплексов Калиновского курганного могильника дают возможность поставить вопрос о включении нового этнического компонента в сарматскую среду, который продолжал использовать данный курганный могильник. Но использование этого могильника было весьма специфичным. Практически в позднесарматское время не использовались для захоронений те курганы, в которых сосредоточена основная масса погребений раннесарматского и среднесарматского времени (кург. 3, 8, 12). Из шести впускных погребений позднесарматской культуры только одно детское захоронение, слабо документированное в отношении его даты, было обнаружено в кургане 8 (погр. 18). Остальные, 21 погребение, находясь под индивидуальными насыпями, являлись самостоятельными погребальными комплексами. Влияние нового населения, видимо, было значительным, поскольку привело к смене наиболее консервативного элемента культуры, которым является погребальный обряд. Не исключено, что какая-то часть прежнего населения вошла в состав, по всей видимости, нового племенного образования и продолжала использовать прежний могильник. Об этом свидетельству- 
ет сохранение южной ориентировки погребенных в 6 случаях (22,2\%), сооружение погребений в подквадратных ямах с диагональным положением умерших. Последняя деталь обряда была широко распространена в среднесарматское время.

\section{Анализ антропологического материала}

Важную роль в выявлении преемственности и притока новых групп мигрантов играет антропологический материал. В процессе раскопок Калиновского могильника была собрана и опубликована массовая репрезентативная серия костного материала В.В. Гинзбургом. В таблице 2 его статьи приводятся половозрастные определения костяков и типологическая диагностика черепов. К различным периодам сарматской культуры относится материал, насчитывающий 100 костяков [Гинзбург, 1959, табл. 2, с. 526-533]. Этот антропологический материал исследовался нами с учетом современных культурно-хронологических определений по программе краниологического исследований.

Согласно тех культурно-хронологических определений, которые В.В. Гинзбургу, видимо, дал В.П. Шилов, материал распределяется по группам следующим образом:

- к савроматскому времени - 1 ;

- к раннесарматскому - 47;

- к среднесарматскому - 27;

- к позднесарматскому - 26 [Гинзбург, 1959 , табл. 2, с. 526-533].

Несколько иное распределение материала автор дает при индивидуальной характеристике черепов:

- к савроматскому времени - 1 ;

- к раннесарматскому - 35;

- к среднесарматскому - 26;

- к позднесарматскому - 23 [Гинзбург, 1959 , табл. 4 , с. $544-551$, табл. 5, с. 554-561, табл. 6, с. 566-572].

Анализируя антропологический материал индивидуально-типологическим методом, В.В. Гинзбург отмечает, что на протяжении всей сарматской эпохи расовый тип населения эпохи раннего железного века претерпевает ряд изменений:

1) к позднему этапу происходит сдвиг в сторону монголоидности;
2) к позднему этапу черепная коробка приобретает более высокую и узкую форму с более покатым лбом и резко развитым надпереносьем и надбровными дугами [Гинзбург, 1959, с. 573-575]. Он считает, что вышеприведенные изменения связаны как с притоком новых групп, так и с практикой обычая искусственной деформации головы.

Кроме этого автор отмечает и примесь «иных антропологических типов». Основной тип сарматского населения - могильник Калиновка - В.В. Гинзбург определяет как степной. Черепа этого типа составляют абсолютное большинство во всех трех хронологических группах [Гинзбург, 1959, табл. 8, с. 573]. Значительное количество черепов всех трех этапов сарматской культуры автор относит к андроновскому типу, а в раннесарматское и среднесарматское время имеются черепа средиземноморского комплекса. Серию позднесарматского времени отличает от предшествующего времени наличие «проевропеоидного комплекса». Кроме того, на нескольких черепах раннесарматского и позднесарматского периодов В.В. Гинзбург диагностирует незначительную примесь типа среднеазиатского междуречья. И, наконец, на рубеже эр появляется примесь монголоидной расы в виде черепов смешанного типа.

Более подробно В.В. Гинзбург рассматривает краниотип у населения позднесарматского времени, который определяет как европеоидный с возможной монголоидной примесью. Такое сочетание признаков, по его мнению, отражает еще большую смешанность, чем у их предшественников, и связи как с востоком (Западный Казахстан), так и с западом, поскольку «долихо-мезокранный тип напоминает черепа из Салтовского могильника и аланских могильников Северного Кавказа» [Гинзбург, 1959, с. 573].

Отдельное внимание В.В. Гинзбург уделяет в этой работе обычаю искусственной деформации головы. По его наблюдениям, больше половины позднесарматских черепов несут следы искусственной деформации. Преобладает деформация лобно-затылочного типа, хотя встречаются и другие типы. Чаще всего лобно-затылочная деформация сочетается с кольцевой. В результате давления деформирующей конструкции, по мнению авто- 
ра, увеличивается высота черепного свода и усиливается угол наклона лба. Различные изменения под влиянием деформирующей конструкции претерпевают продольный, скуловой диаметры, а также углы горизонтальной профилировки. Данные тенденции, по мнению автора, свидетельствуют о том, что «...деформации подвергались индивиды разного расового типа» [Гинзбург, 1959, с. 572].

Таким образом, В.В. Гинзбург на основе наличия в трех хронологических группах черепов с различными антропологическими типами отмечает смешанный характер исследуемого сарматского населения, но, как считает автор: «постепенно у них развилась общая культура... традиция деформировать голову» [Гинзбург, 1959, с. 575].

Материал, опубликованный В.В. Гинзбургом с учетом вышепредложенных изменений в культурно-хронологической атрибутике моим соавтором, был пересмотрен. После проведенной работы материал распределился по культурно-хронологическим группам следующим образом:

1) серия раннесарматского времени насчитывает - 32 черепа (15 мужских и 17 женских) (табл. 1, 2);

2) серия среднесарматского времени 21 череп (9 мужских и 12 женских) (табл. 1, 2);

3 ) серия позднесарматского времени 17 черепов (14 мужских и 3 женских) (табл. 3).

Для решения поставленной задачи в данной части статьи дается общая характеристика краниологического типа культурно-хронологических периодов и сопоставление краниологических серий могильника между собой и положение их на фоне других сарматских серий.

Сравнительная характеристика общего типа раннесарматского и среднесарматского мужского населения, оставившего могильник Калиновка, показывает незначительные различия, которые сводятся к более узкой черепной коробке в среднесарматской группе (табл. 1). В связи с этим она приобретает мезокранную форму, в отличие от раннесарматской брахикранной формы. Кроме этого, на среднем этапе лицевой скелет с ослабленной горизонтальной профилировкой на обоих уровнях, а нос средневыступающий по сравнению с краниологическим типом населения раннего этапа. У них небольшое уплощение лица на уровне глазниц, а нос выступает резко к линии профиля.

Вышеприведенные незначительные различия мужских серий позволяют предположить, что среднесарматский временной пласт составляло местное население, на которое накладывалось пришлое население, в облике которого улавливаются восточные элементы.

Что касается женских культурно-хронологических групп, то различия у них такие же, как и в мужских группах, но еще более несущественные (табл. 2). Незначительное сужение мозговой коробки у среднесарматской группы по сравнению с раннесарматской привело к тому, что черепной указатель находится на границе брахикранных и мезокранных форм. Снижение черепного свода вместе с сужением привело к тому, что и условный трансверсальный объем и сечение меньше, чем в более ранней группе. Лицевой отдел, грушевидное отверстие, орбита, переносье и носовые кости также претерпели незначительные изменения, они шире в среднесарматской группе. Как и у мужчин горизонтальная профилировка в раннесарматской группе умеренная лишь на верхнем уровне, а в среднесарматской - на обоих.

Таким образом, несмотря на незначительные изменения в морфологическом облике женского населения, намечаются те же тенденции, что и у мужчин.

Сопоставление мужских групп раннесарматского и среднесарматского времени с позднесарматским показывает уже более существенные различия (табл. 1-3). Прежде всего следует указать на различия в мозговом отделе черепа. Обе группы со следами деформации и без деформации длиннее и уже серий предшествующего времени, а по черепному указателю обе мужские группы долихокранные. Различия между обеими позднесарматскими мужскими группами связаны с эффектом деформации. Так, свод выше, а лобная кость шире и покатее в серии со следами деформации. Лицевой скелет и его отдельные части, видимо, тоже находились под давлением деформирующей конструкции. Он широкий, высокий и с резкой горизонтальной профилировкой. Нос и глазницы также выше и шире в деформированной группе, а вот угол высту- 
пания носа в недеформированной серии выступает резче, хотя лицо и с ослабленной горизонтальной профилировкой на обоих уровнях.

Небольшая женская серия деформированных черепов позднесарматского времени отличается от мужской. Мозговой отдел брахикранный с высоким сводом, а лицевой отдел с умеренной горизонтальной профилировкой на обеих уровнях.

Специфика краниологических типов у населения позднесарматского времени позволяет говорить о двух пришлых компонентах: у одного преобладал тип длинноголовых европеоидов, у другого смешанные черты европеоидно-монголоидных метисов. Наличие смешанных расовых вариантов у позднесарматского населения отмечал и В.В. Гинзбург $[1959$, c. 571$]$.

Таким образом, даже простое сопоставление средних значений культурно-хронологических серий позволяет говорить о сходстве первых двух периодов и существенном отличии от них позднего антропологического пласта.

Данные тенденции отчетливо просматриваются и при рассмотрении культурно-хронологических групп из Калиновки на фоне синхронного населения. На первом этапе сравнивались серии раннесарматского и среднесарматского времени (табл. 4), а на втором позднесарматские группы между собой (табл. 5).

Сопоставление серий раннесарматского и среднесарматского времени проводилось каноническим методом, в который были включены 42 мужские и 30 женских серии. Результаты анализа показали как определенное сходство первых двух хронологических пластов мужского населения, так и некоторое различие, что демонстрирует и многомерный анализ по 14 краниологическим признакам $(1 ; 8$; 17; 9; 45; 48; 77; <zm'; 54; 55; 51; 52; SS:SC; 75-1) (табл. 4).

Сопоставление 24 раннесарматских и 18 среднесарматских мужских групп показывает, что в совокупности наибольшие нагрузки по I КВ падают на серии, у которых мозговая коробка и лицо широкие, а черепной свод низкий (положительный полюс изменчивости). Соответственно узкоголовые и узколицые серии с высоким сводом черепом будут иметь максимальные отрицательные нагрузки. Причем вклад I КВ в межгрупповую изменчивость значительный - около 30 \% (табл. 4).

Первый набор признаков характерен для раннесарматских серий, причем восточной локализации (Мечет Сай, Калмыково, Новый Кумак, Старые Киишки и др.), а второй - для преимущественно среднесарматских (Колобовка, Канал Волга-Чограй, Кузин, Первомайский) и раннесарматских (Новый, Перегрузное I, Маляевка и др.) западной локализации.

Таким образом, первую дискриминанту можно воспринимать как переменную, которая разграничивает типы по культурно-хронологическим периодам: раннесарматскому и среднесарматскому и по широтному градиенту (3-В). Второй и третий канонические векторы при анализе мужских групп в общей сложности отражают около $31,4 \%$ от общей межгрупповой изменчивости и они различают группы по носовым признакам: симотический указатель и угол выступания носа к линии профиля (SS:SC и 75-1) (II КВ) и по высоте свода и ширине орбиты (17 и 51) (III КВ).

Сходство и различие отдельных мужских групп раннесарматского и среднесарматского времени демонстрирует четырехпольный график многомерного неметрического шкалирования и дендрограмму кластеризации расстояний Махаланобиса (рис. 1). Так, группа раннесарматского времени из Калиновки по расстояниям Махаланобиса демонстрирует близость с большей частью синхронных раннесарматских серий (Бережновка II; Быково; Верхний Балыклей, Старица, Батаевка и др.) и с сериями среднесарматского времени, в облике которых преобладает субстратный раннесарматский пласт (Калиновка, УстьКаменка, Жутово, Первомайский и др.). В результате кластеризации мужская раннесарматская серия оказалась в группе с синхронными сериями из Кара Оба, Батаевки, Бережновки II и Усть-Каменки среднесарматского времени. Что касается среднесарматской группы из Калиновки, то связь ее с другими сарматскими сериями по расстояниям Махаланобиса меньше, чем у ранней, что, видимо, отражает их различия и позволяет интерпретировать результаты сопоставлений мужских серий из Калиновки раннесарматского и среднесарматского времени как с позиций сохра- 
нения большей части субстратного населения в среднесарматское время, так и с внедрением новой группы мигрантов.

Для определения положения женских групп на фоне синхронного сарматского населения в канонический анализ были включены 18 серий раннесарматского и 12 среднесарматского времени (табл. 4). Первый канонический вектор имеет гораздо меньший вклад в межгрупповую изменчивость, чем при анализе мужских групп, и составляет около $23 \%$ от общей изменчивости, тем самым демонстрируя большее сходство женского населения раннего и среднего хронологических пластов, чем мужского. Различия между группами по этой переменной сказываются по поперечному и продольному диаметрам и ширине орбиты $(1 ; 8 ; 51)$. Согласно этим данным, короткая и широкая мозговая коробка и глазница (положительный полюс изменчивости) чаще являются морфологической доминантой в первую очередь раннесарматских серий (Степной, Кардаилово, Быково и др.), а длинная узкая мозговая коробка и глазница (отрицательный полюс изменчивости) - как раннесарматских (Верхнепогромное, Красный Октябрь и др.), так и среднесарматских (Старица, Аксай и др.). На II и III КВ в сумме приходится около 35,8 \% от общей межгрупповой изменчивости. Второй канонический вектор КВ связан высокими корреляциями с высотой свода, скуловой шириной и назомалярным углом $(17 ; 45 ; 77)$. Сочетание: высокий свод, узкое умеренно профилированное лицо на верхнем уровне (положительный полюс изменчивости) встречаются в отдельных локальных группах обоих периодов (раннесарматские серии: Степной $\mathrm{IV}$, Первомайский, Верхнепогромное; среднесарматские серии: Первомайский и др.). Альтернативный тип встречается в раннесарматской группе из могильника Старые Киишки и в среднесарматских группах из территории Украины. На III КВ выпадают корреляции с высотой носа и глазницы $(55 ; 52)$. Здесь вектор разграничивает группы с низким носом и высокой глазницей (среднесарматские серии: Терновский, Аксай; раннесарматские: Старица и др.) от серий, у которых высокий нос и низкая глазница (обе хронологические серии из Калиновки, Крепь и др.).
Расположение женских групп на четырехпольном графике многомерного неметрического шкалирования, а также результаты кластерного анализа не так сильно разобщены, как у мужских групп (рис. 2). Как и при сравнении мужских групп, женские хронологические группы из Калиновки имеют сходство с обеими хронологическими группами различной локализации. Группа раннесарматского времени из Калиновки оказалась в тесной связи с раннесарматской группой из Первомайского могильника, с среднесарматской группой из Калиновки и могильника Крепь.

Кроме сопоставления раннесарматских и среднесарматских серий был проведен канонический анализ позднесарматских серий. Изучались лишь мужские группы, так как женская серия из Калиновки насчитывает три черепа плохой сохранности. Результаты анализа показали, что наибольшая изменчивость выпадает на первые три вектора, более 55,0 \% от общей изменчивости, они и рассматриваются ниже (табл. 5).

По первой дискриминанте, на которую приходится более 28,0 \% при анализе мужских серий, высокие положительные корреляции имеет только высотный диаметр (17), а значимые отрицательные нагрузки - поперечный диаметр (8) и симотический указатель (SS:SC). Таким образом, I KВ отражает различия между группами, которые связаны с комплексом деформации, то есть тем комплексом признаков, который меняется под действием давящей повязки. Несмотря на то что далеко не весь набор признаков деформации включен в канонический анализ, тем не менее, положительные значения по I КВ имеют только деформированные, а отрицательные - недеформированные разнополые группы.

Вторая переменная у мужчин разграничивает узкоголовый тип в сочетании с высокими умеренно выступающими носовыми костями от широкоголового с низкими резко выступающими носовыми костями. Первый вариант наиболее характерен для групп, локализованных в районе Есауловского Аксая, притока Дона и прилежащих территорий, могильники: Абганерово II (обе группы: деформированная и недеформированная), деформированные группы из Абганерово IV, Аксая, Купцын Толги и др. Группа деформированных 
черепов из Калиновки по значениям выходит на положительный полюс. Второй вариант в наибольшей степени представлен в деформированных группах с территории Калмыкии: У85; Три Брата, Дюкер и в какой-то степени встречается в группе недеформированных черепов из Калиновки.

Таким образом, на основе канонического анализа удалось выделить комплекс деформации, который включает серии с узким поперечным диаметром, высоким сводом и относительно низкими носовыми костями. Двумя другими существенными морфологическими вариантами позднесарматских групп являются узкоголовые и широкоголовые типы, так как поперечный диаметр по первым трем каноническим векторам при анализе мужских групп имеет высокие отрицательные значения.

Вышеописанные тенденции изменчивости между сериями из отдельно взятых могильников наглядно прослеживаются на четырехпольном графике многомерного неметрического шкалирования расстояний Махаланобиса (рис. 3).

Общая изменчивость и особенности рассеивания мужских краниологических серий на корреляционном поле показывают, что большая часть деформированных серий расположилась на отрицательном поле графика, а недеформированные - на положительном (рис. 3). Наиболее компактное расположение серий свидетельствует об их морфологическом сходстве. Обе мужские серии из Калиновки не выделяются из общего рассеивания групп на четырехпольном графике.

\section{Результаты исследования \\ и основные выводы}

Из всего вышеизложенного можно сделать следующие выводы. Смена сарматских культур не происходила по какому-то одному сценарию на обширных пространствах ДоноВолго-Уральского степного региона и Северного Причерноморья, она носила мозаичный характер. Становление практически всех сарматских культур связано с миграционными процессами, с взаимодействием мигрантов и субстратного местного населения. В разных районах указанного выше огромного степно- го пространства этот процесс проходил поразному, в зависимости от роли того или иного этнического компонента.

Так, например, на начало заключительного этапа раннесарматской культуры (II в. до н.э.) приходятся миграции, существенно изменившие этническую карту на огромной территории от Средней Азии до Северного Причерноморья включительно. Причиной этих миграций были центральноазиатские события, связанные с образованием кочевой империи хунну и их агрессивной политикой по отношению к своим соседям. В сарматских памятниках II-I вв. до н.э. от Дона до Южного Приуралья происходят изменения, частично отразившиеся в погребальном обряде и материальной культуре. Но в этом регионе как в погребальном обряде, так и в материальной культуре ведущее положение сохраняют традиции предшествующей раннесарматской культуры, поскольку здесь ранее сложились и существенно укоренились основные элементы этой культуры. В Северном Причерноморье те же миграционные процессы привели к формированию целого ряда элементов культуры, существенно отличающихся от синхронных памятников к востоку от Дона. Это объяснятся тем, что в Северном Причерноморье отсутствовал мощный пласт раннесарматской культуры предшествующего времени.

Различия во взаимодействии инновационных и местных элементов в развитии сарматских культур ощущаются и на более ограниченных территориях. Так, для заволжской территории Нижнего Поволжья практически не фиксируется в сарматских памятниках II-I вв. до н.э. влияние центральноазиатских элементов культуры. Однако они хорошо представлены в междуречье Дона и Волги, в частности в бассейне Иловли, левого притока Дона [Скрипкин, 2014, с. 218-222].

Даже в Заволжье комплектация курганных могильников зачастую существенно различается. Так, например, в Сусловском курганном могильнике, располагавшемся в Саратовской области на берегу реки Большой Караман, левом притоке Волги, исследованном П.С. Рыковым в 1924 и 1926 гг., было раскопано 70 курганов, древнейшие захоронения в них относились к бронзовому веку, одно по- 
гребение датируется савроматским временем, полностью отсутствуют раннесарматские захоронения, погребений среднесарматской культуры было открыто 36, позднесарматской 17 [Рыков, 1925; Скрипкин, 1998, с. 104-124]. Судя по материалам этого могильника, носители среднесарматской культуры не испытывали существенного влияния населения раннесарматского времени. Здесь среднесарматская культура предстает в наиболее чистом своем виде, без каких-либо влияний предшествующей сарматской культуры. Основные среднесарматские погребения в могильнике занимают ведущие позиции $(88,9$ \%), наиболее распространенным типом захоронений являются диагональные погребения (41,7 \%). Погребальный инвентарь хорошо укладывается во временные рамки, принятые для среднесарматской культуры, преимущественно Iпервая половина II в. н.э. Не случайно Сусловский курганный могильник являлся эпонимным памятником среднесарматской культуры (сусловская культура).

Полагаем, что изучение становления и развития сарматских культур в настоящее время должно обязательно учитывать анализ погребальных комплексов отдельно взятых могильников с целью выяснения сходства и различий в них разновременных сарматских культур по данным археологии, параллельно необходимо изучение антропологических коллекций с того же могильника. Сопоставление археологических и антропологических данных позволяет создать наиболее объективную картину взаимодействия местного и пришлого компонента данного памятника. Корреляция могильников по степени сходства этих процессов позволит воссоздать общую картину этноисторических процессов того или иного изучаемого региона.
Результаты исследования антропологического материала из могильника Калиновка позволяют выделить главные морфологические критерии, которые определяют антропологическое своеобразие исследуемого населения. Прежде всего следует отметить то, что по морфологическим параметрам население раннесарматского и среднесарматского времени, оставившее могильник Калиновка, обладает определенным сходством, которое одновременно является, видимо, и генетическим. Объяснить такое распределение межгрупповой и внутригрупповой изменчивости можно тем, что у этих групп имеется единое этническое или морфологическое ядро, которое их и объединяет. Для среднесарматского времени оно является субстратом, на который накладывался тип немногочисленных пришлых, очевидно, восточных компонентов. По своим качествам субстрат представлял собой тип древних восточных европеоидов или степной тип по В.В. Гинзбургу, сочетающий умеренную брахикранию с небольшим уплощением на верхнем лицевом уровне, а суперстрат можно связать с притоком мигрантов восточного происхождения, на что указывает уплощение лицевого профиля уже на обоих горизонтальных уровнях.

Вышеприведенное исследование позволило установить сходство обеих позднесарматских мужских групп из могильника Калиновка с остальным населением, оставившим отдельные могильники. Причем, как и во всем массиве позднесарматских серий, различия между калиновскими группами связаны с комплексом деформации, то есть различия по признакам, претерпевающим изменения в процессе роста и развития под давлением деформирующей конструкции. 
M.A. Balabanova, A.S. Skripkin. On the Succession of Sarmatian Cultures and Population

\section{ИЛЛЮСТРАЦИИ}

Таблииа 1

Средние размеры и указатели мужских краниологических серий из могильника Калиновка

\begin{tabular}{|c|c|c|c|c|c|c|}
\hline \multirow{2}{*}{$\begin{array}{c}\text { № по } \\
\text { Мартину и др. }\end{array}$} & \multicolumn{3}{|c|}{ Раннесарматское время } & \multicolumn{3}{|c|}{ Среднесарматское время } \\
\hline & $n$ & $X$ & $S$ & $n$ & $X$ & $S$ \\
\hline 1 & 15 & 183,0 & 6,7 & 9 & 183,0 & 8,6 \\
\hline 8 & 15 & 146,2 & 4,3 & 9 & 141,8 & 6,3 \\
\hline $8: 1$ & 15 & 80,0 & 4,4 & 9 & 77,7 & 5,5 \\
\hline 17 & 10 & 133,5 & 5,0 & 3 & 132,7 & 1,5 \\
\hline $17: 1$ & 10 & 73,1 & 3,6 & 3 & 73,2 & 1,8 \\
\hline $17: 8$ & 10 & 92,0 & 4,1 & 3 & 91,3 & 0,4 \\
\hline OPB & 10 & 269,5 & 4,1 & 3 & 267,6 & 2,2 \\
\hline $\mathrm{M} 2$ & 15 & 267,4 & 9,5 & 9 & 259,3 & 14,6 \\
\hline M3 & 10 & 1771,2 & 92,5 & 3 & 1748,1 & 38,6 \\
\hline 5 & 8 & 101,2 & 3,0 & 3 & 102,7 & 2,5 \\
\hline 20 & 14 & 116,3 & 3,3 & 8 & 116,0 & 5,3 \\
\hline 9 & 14 & 96,2 & 4,2 & 8 & 96,25 & 5,8 \\
\hline 11 & 14 & 132,2 & 5,1 & 7 & 132,9 & 3,7 \\
\hline 45 & 11 & 134,9 & 7,5 & 9 & 131,8 & 7,2 \\
\hline 40 & 7 & 96,7 & 4,4 & 3 & 95,7 & 2,3 \\
\hline $40: 5$ & 7 & 95,2 & 1,9 & 3 & 93,2 & 0,9 \\
\hline 48 & 12 & 70,5 & 3,4 & 9 & 71,0 & 4,3 \\
\hline 54 & 12 & 24,8 & 2,0 & 9 & 24,1 & 2,3 \\
\hline 55 & 12 & 51,8 & 2,6 & 9 & 52,2 & 3,3 \\
\hline $54: 55$ & 12 & 48,2 & 2,8 & 9 & 46,2 & 4,1 \\
\hline 51 & 11 & 42,6 & 2,2 & 7 & 42,1 & 2,7 \\
\hline 52 & 11 & 33,6 & 2,7 & 9 & 31,9 & 1,8 \\
\hline $52: 51$ & 11 & 78,5 & 4,7 & 7 & 75,8 & 4,8 \\
\hline $\mathrm{DC}$ & 13 & 20,7 & 3,9 & 5 & 20,7 & 3,5 \\
\hline DS & 13 & 12,2 & 1,2 & 5 & 13,0 & 2,2 \\
\hline $\mathrm{DS}: \mathrm{DC}$ & 13 & 61,4 & 9,3 & 5 & 64,0 & 12,2 \\
\hline $\mathrm{SC}$ & 13 & 8,6 & 1,4 & 5 & 9,1 & 2,5 \\
\hline $\mathrm{SS}$ & 13 & 4,4 & 0,8 & 5 & 4,6 & 0,7 \\
\hline $\mathrm{SS}: \mathrm{SC}$ & 13 & 51,9 & 9,7 & 5 & 52,8 & 7,7 \\
\hline 77 & 15 & 140,8 & 3,6 & 9 & 141,8 & 6,8 \\
\hline$<\mathrm{zm}^{\prime}$ & 14 & 127,6 & 4,0 & 9 & 131,6 & 5,0 \\
\hline 32 & 14 & 82,7 & 5,4 & 8 & 82,8 & 5,5 \\
\hline 72 & 13 & 84,7 & 2,8 & 6 & 85,0 & 3,8 \\
\hline 74 & 13 & 75,5 & 7,6 & 6 & 75,3 & 7,5 \\
\hline $75-1$ & 11 & 29,5 & 5,7 & 5 & 26,0 & 6,8 \\
\hline
\end{tabular}

Таблицьа 2

\section{Средние размеры и указатели женских краниологических серий} из могильника Калиновка

\begin{tabular}{|c|r|r|r|r|r|r|}
\hline \multirow{2}{*}{$\begin{array}{c}\text { № по } \\
\text { Мартину и др. }\end{array}$} & \multicolumn{3}{|c|}{ Раннесарматское время } & \multicolumn{3}{c|}{ Среднесарматское время } \\
\cline { 2 - 7 } & \multicolumn{1}{|c|}{$n$} & \multicolumn{1}{c|}{$s$} & \multicolumn{1}{c|}{$n$} & \multicolumn{1}{c|}{$s$} \\
\hline 1 & 17 & 175,6 & 7,2 & 12 & 174,3 & 5,0 \\
\hline 8 & 17 & 141,3 & 4,8 & 12 & 138,7 & 6,6 \\
\hline $8: 1$ & 17 & 80,6 & 4,2 & 12 & 79,65 & 5,4 \\
\hline 17 & 11 & 127,9 & 5,8 & 4 & 121,0 & 2,4 \\
\hline $17: 1$ & 11 & 72,4 & 3,2 & 4 & 69,1 & 2,0 \\
\hline $17: 8$ & 11 & 90,1 & 3,6 & 4 & 88,2 & 3,1 \\
\hline OРВ & 11 & 260,4 & 6,4 & 4 & 253,4 & 5,6 \\
\hline M2 & 17 & 248,1 & 13,9 & 12 & 241,7 & 8,7 \\
\hline M3 & 11 & 1606,6 & 125,9 & 4 & 1455,9 & 85,0 \\
\hline
\end{tabular}


М.А. Балабанова, А.С. Скрипкин. О преемственности сарматских культур и населения

Окончание таблицы 2

\begin{tabular}{|c|c|c|c|c|c|c|}
\hline \multirow{2}{*}{$\begin{array}{c}№ \text { по } \\
\text { Мартину и др. }\end{array}$} & \multicolumn{3}{|c|}{ Раннесарматское время } & \multicolumn{3}{|c|}{ Среднесарматское время } \\
\hline & $n$ & $X$ & $s$ & $n$ & $X$ & $s$ \\
\hline 5 & 11 & 98,1 & 3,5 & 4 & 94,0 & 3,65 \\
\hline 20 & 17 & 113,7 & 5,1 & 10 & 110,8 & 3,3 \\
\hline 9 & 17 & 95,2 & 4,6 & 12 & 94,9 & 5,3 \\
\hline 11 & 17 & 124,9 & 5,7 & 10 & 125,9 & 7,1 \\
\hline 45 & 17 & 126,7 & 4,1 & 11 & 128,7 & 7,3 \\
\hline 40 & 11 & 98,9 & 4,5 & 4 & 91,0 & 1,8 \\
\hline $40: 5$ & 11 & 97,9 & 3,65 & 4 & 96,9 & 3,7 \\
\hline 48 & 17 & 65,4 & 3,4 & 12 & 65,3 & 3,1 \\
\hline 54 & 17 & 23,2 & 1,7 & 12 & 25,0 & 2,0 \\
\hline 55 & 17 & 50,1 & 4,2 & 12 & 48,4 & 2,9 \\
\hline $54: 55$ & 17 & 46,5 & 4,3 & 12 & 51,8 & 4,6 \\
\hline 51 & 17 & 41,8 & 1,4 & 11 & 42,3 & 2,3 \\
\hline 52 & 17 & 32,2 & 1,5 & 12 & 32,0 & 2,2 \\
\hline $52: 51$ & 17 & 77,0 & 4,3 & 12 & 75,1 & 4,2 \\
\hline$\overline{\mathrm{DC}}$ & 16 & 19,4 & 1,9 & 9 & 21,6 & 2,8 \\
\hline DS & 16 & 11,3 & 2,4 & 8 & 11,1 & 1,7 \\
\hline DS:DC & 16 & 58,9 & 14,9 & 8 & 52,4 & 9,8 \\
\hline $\mathrm{SC}$ & 16 & 9,1 & 1,7 & 9 & 9,7 & 1,7 \\
\hline SS & 16 & 4,1 & 0,7 & 9 & 4,0 & 1,1 \\
\hline SS:SC & 16 & 46,0 & 10,85 & 9 & 41,1 & 8,0 \\
\hline 77 & 16 & 142,9 & 5,0 & 12 & 141,9 & 3,4 \\
\hline$<\mathrm{zm}^{\prime}$ & 17 & 129,5 & 4,5 & 10 & 131,8 & 6,8 \\
\hline 32 & 17 & 83,9 & 5,2 & 9 & 83,8 & 5,0 \\
\hline 72 & 16 & 83,4 & 4,1 & 9 & 85,8 & 3,7 \\
\hline 74 & 16 & 74,9 & 7,4 & 7 & 74,9 & 4,7 \\
\hline $75-1$ & 15 & 26,0 & 5,1 & 8 & 27,4 & 7,0 \\
\hline
\end{tabular}

Таблииа 3

\section{Средние размеры и указатели мужских краниологических серий} позднесарматского времени

\begin{tabular}{|c|c|c|c|c|c|c|c|c|c|}
\hline \multirow{3}{*}{$\begin{array}{c}\text { № по } \\
\text { Мартину и др. }\end{array}$} & \multicolumn{6}{|c|}{ Мужчины } & \multirow{2}{*}{\multicolumn{3}{|c|}{$\begin{array}{c}\text { Женщины } \\
\text { со следами искусственной } \\
\text { деформации }\end{array}$}} \\
\hline & \multicolumn{3}{|c|}{$\begin{array}{c}\text { без искусственной } \\
\text { деформации }\end{array}$} & \multicolumn{3}{|c|}{$\begin{array}{c}\text { со следами искусственной } \\
\text { деформации }\end{array}$} & & & \\
\hline & $n$ & $X$ & $s$ & $n$ & $X$ & $s$ & $n$ & $X$ & $s$ \\
\hline 1 & 3 & 185,0 & 1,7 & 10 & 185,6 & 5,4 & 2 & 163,5 & \\
\hline 8 & 4 & 136,8 & 3,9 & 10 & 137,8 & 6,2 & 3 & 137,7 & 6,7 \\
\hline $8: 1$ & 3 & 74,6 & 2,5 & 10 & 74,3 & 3,3 & 2 & 83,1 & \\
\hline 17 & 3 & 128,0 & 3,6 & 10 & 141,2 & 6,0 & 1 & 133 & \\
\hline $17: 1$ & 3 & 69,2 & 2,6 & 10 & 76,1 & 2,8 & 1 & 78,2 & \\
\hline $17: 8$ & 3 & 92,8 & 2,6 & 10 & 102,7 & 6,7 & 1 & 102,3 & \\
\hline OPB & 3 & 264,0 & 2,0 & 10 & 271,0 & 7,2 & 1 & 252,0 & \\
\hline M2 & 3 & 255,2 & 5,2 & 10 & 255,9 & 15,6 & 2 & 221,2 & \\
\hline M3 & 3 & 1633,9 & 62,1 & 10 & 1807,1 & 146,5 & 1 & 1469,65 & \\
\hline 5 & 3 & 99,7 & 2,3 & 10 & 108,7 & 5,4 & 1 & 96 & \\
\hline 20 & 4 & 113,5 & 5,3 & 10 & 120,9 & 4,7 & 3 & 123,7 & 7,6 \\
\hline 9 & 4 & 94,5 & 3,1 & 10 & 98,7 & 5,7 & 3 & 100,0 & 7,8 \\
\hline 11 & 4 & 125,8 & 4,2 & 10 & 130,6 & 6,4 & 3 & 125,3 & 5,7 \\
\hline 45 & 4 & 133,0 & 4,2 & 10 & 137,9 & 7,0 & 3 & 127,3 & 3,2 \\
\hline 40 & 3 & 97,0 & 4,0 & 10 & 102,9 & 4,3 & 1 & 93 & \\
\hline $40: 5$ & 3 & 97,4 & 4,6 & 10 & 93,1 & 3,8 & 1 & 96,9 & \\
\hline 48 & 4 & 70,2 & 3,0 & 10 & 74,6 & 5,1 & 3 & 71,7 & 3,5 \\
\hline 54 & 4 & 24,5 & 1,3 & 10 & 25,6 & 1,9 & 3 & 22,7 & 1,5 \\
\hline 55 & 4 & 53,2 & 2,1 & 10 & 54,9 & 4,8 & 3 & 50,7 & 2,5 \\
\hline $54: 55$ & 4 & 46,1 & 3,8 & 10 & 46,9 & 5,0 & 3 & 44,9 & 5,2 \\
\hline 51 & 4 & 41,5 & 0,6 & 10 & 44,1 & 2,7 & 3 & 41,3 & 1,5 \\
\hline
\end{tabular}


M.A. Balabanova, A.S. Skripkin. On the Succession of Sarmatian Cultures and Population

Окончание таблицы 3

\begin{tabular}{|c|c|c|c|c|c|c|c|c|c|}
\hline \multirow{3}{*}{$\begin{array}{c}\text { № по } \\
\text { Мартину и др. }\end{array}$} & \multicolumn{6}{|c|}{ Мужчины } & \multirow{2}{*}{\multicolumn{3}{|c|}{$\begin{array}{c}\text { Женщины } \\
\text { со следами искусственной } \\
\text { деформации }\end{array}$}} \\
\hline & \multicolumn{3}{|c|}{$\begin{array}{l}\text { без искусственной } \\
\text { деформации }\end{array}$} & \multicolumn{3}{|c|}{$\begin{array}{c}\text { со следами искусственной } \\
\text { деформации }\end{array}$} & & & \\
\hline & $n$ & $X$ & $s$ & $n$ & $X$ & $s$ & $n$ & $X$ & $s$ \\
\hline 52 & 4 & 32,2 & 1,0 & 10 & 35,5 & 3,1 & 3 & 37,0 & 2,0 \\
\hline $52: 51$ & 4 & 77,7 & 1,4 & 10 & 79,8 & 7,5 & 3 & 89,6 & 4,9 \\
\hline $\mathrm{DC}$ & 4 & 20,6 & 2,1 & 10 & 21,5 & 3,7 & 3 & 25,5 & 4,5 \\
\hline DS & 4 & 12,4 & 1,4 & 10 & 12,5 & 2,1 & 3 & 11,1 & 1,0 \\
\hline DS:DC & 4 & 60,5 & 8,7 & 10 & 58,8 & 10,7 & 3 & 46,2 & 10,8 \\
\hline $\mathrm{SC}$ & 4 & 8,8 & 1,0 & 10 & 8,9 & 1,9 & 3 & 9,9 & 2,1 \\
\hline SS & 4 & 3,9 & 0,6 & 10 & 4,6 & 1,2 & 3 & 3,7 & 0,8 \\
\hline SS:SC & 4 & 44,3 & 3,9 & 10 & 52,7 & 15,4 & 3 & 39,4 & 148 \\
\hline 77 & 4 & 141,6 & 2,5 & 10 & 138,1 & 6,1 & 3 & 141,9 & 7,4 \\
\hline$<\mathrm{zm}^{\prime}$ & 4 & 132,2 & 3,2 & 10 & 128,9 & 4,3 & 3 & 136,7 & 13,05 \\
\hline 32 & 4 & 79,2 & 5,1 & 10 & 74,7 & 5,7 & 3 & 80,0 & 7,9 \\
\hline 72 & 4 & 86,5 & 3,5 & 10 & 86,2 & 3,5 & 3 & 85,0 & 7,0 \\
\hline 74 & 4 & 80,0 & 7,3 & 10 & 78,3 & 6,8 & 3 & 72,3 & 11,2 \\
\hline $75-1$ & 4 & 31,2 & 8,1 & 10 & 26,8 & 4,1 & 3 & 25,7 & 1,2 \\
\hline
\end{tabular}

Таблиияа 4

Результаты первых трех канонических векторов при сравнении раннесарматских и среднесарматских групп

\begin{tabular}{|c|c|c|c|c|c|c|}
\hline \multirow{2}{*}{$\begin{array}{l}\text { № по Мартину и др. / } \\
\text { канонические вектора }\end{array}$} & \multicolumn{3}{|c|}{ Мужчины } & \multicolumn{3}{|c|}{ Женщины } \\
\hline & I & II & III & I & II & III \\
\hline 1 & $-0,376$ & & 0,178 & $-0,557$ & 0,105 & $-0,261$ \\
\hline 8 & 0,687 & $-0,335$ & 0,454 & 0,798 & 0,069 & 0,243 \\
\hline 17 & $-0,658$ & $-0,099$ & 0,679 & 0,119 & 0,659 & 0,321 \\
\hline 9 & $-0,306$ & 0,112 & $-0,141$ & $-0,185$ & 0,132 & 0,087 \\
\hline 45 & 0,554 & 0,147 & $-0,448$ & 0,084 & $-0,876$ & 0,205 \\
\hline 48 & 0,096 & 0,100 & $-0,187$ & 0,267 & $-0,233$ & 0,486 \\
\hline 55 & $-0,083$ & $-0,251$ & 0,301 & $-0,288$ & 0,260 & $-0,789$ \\
\hline 54 & 0,012 & $-0,082$ & $-0,095$ & 0,030 & $-0,005$ & 0,068 \\
\hline 51 & 0,133 & $-0,047$ & 0,725 & 0,529 & 0,445 & $-0,215$ \\
\hline 52 & $-0,048$ & 0,176 & $-0,059$ & $-0,317$ & 0,037 & $\mathbf{0 , 7 2 4}$ \\
\hline 77 & $-0,122$ & 0,328 & 0,118 & $-0,066$ & $\mathbf{0 , 5 3 7}$ & $-0,255$ \\
\hline$<\mathrm{zm}^{\prime}$ & $-0,056$ & 0,047 & 0,002 & 0,062 & $-0,191$ & $-0,042$ \\
\hline SS:SC & 0,202 & 0,744 & 0,110 & $-0,383$ & $-0,042$ & 0,457 \\
\hline $75(1)$ & $-0,277$ & $-1,018$ & $-0,091$ & 0,320 & 0,060 & $-0,445$ \\
\hline Собственные числа & 8,252 & 5,610 & 3,065 & 5,910 & 5,271 & 3,929 \\
\hline \% дисперсии & 29,958 & 20,365 & 11,128 & 22,964 & 20,483 & 15,267 \\
\hline
\end{tabular}

Таблииа 5

Результаты первых трех канонических векторов при сравнении позднесарматских групп с деформацией и без деформации

\begin{tabular}{|c|c|c|c|c|c|c|}
\hline \multirow{2}{*}{$\begin{array}{c}№ \text { по } \\
\text { Мартину и др. }\end{array}$} & \multicolumn{3}{|c|}{ Мужчины } & \multicolumn{3}{|c|}{ Женщины } \\
\hline & I & II & III & I & II & III \\
\hline 1 & $-0,200$ & 0,079 & 0,686 & $-0,027$ & $-0,934$ & 0,301 \\
\hline 8 & $-0,560$ & $-0,524$ & $-0,572$ & $-0,606$ & 0,454 & 0,044 \\
\hline 17 & 0,721 & 0,021 & $-0,326$ & 0,668 & 0,254 & $-0,399$ \\
\hline 9 & 0,154 & $-0,267$ & 0,204 & 0,566 & $-0,137$ & 0,224 \\
\hline 45 & $-0,030$ & 0,312 & $-0,012$ & $-0,099$ & $-0,113$ & $\overline{0,506}$ \\
\hline 48 & 0,117 & $-0,342$ & $-0,174$ & $-0,369$ & 0,272 & 0,198 \\
\hline 55 & 0,066 & 0,270 & 0,182 & 0,385 & $-0,163$ & $-0,221$ \\
\hline 54 & 0,122 & $-0,125$ & $-0,053$ & $-0,121$ & 0,058 & 0,204 \\
\hline 51 & $-0,110$ & 0,180 & 0,431 & $-0,335$ & $-0,009$ & $-0,890$ \\
\hline 52 & 0,470 & 0,086 & $-0,216$ & 0,307 & 0,433 & 0,449 \\
\hline
\end{tabular}


М.А. Балабанова, А.С. Скрипкин. О преемственности сарматских культур и населения

Окончание таблиць 5

\begin{tabular}{|c|c|c|c|c|c|c|}
\hline \multirow{2}{*}{$\begin{array}{c}\text { № по } \\
\text { Мартину и др. }\end{array}$} & \multicolumn{3}{|c|}{ Мужчины } & \multicolumn{3}{|c|}{ Женщины } \\
\hline & I & II & III & I & II & III \\
\hline 77 & $-0,119$ & $-0,103$ & 0,147 & $-0,176$ & $-0,142$ & $-0,123$ \\
\hline$<\mathrm{zm}^{\prime}$ & $-0,026$ & 0,243 & $-0,107$ & $-0,041$ & 0,192 & 0,074 \\
\hline SS:SC & $-0,504$ & 0,842 & $-0,292$ & 0,031 & 0,358 & 0,073 \\
\hline $75-1$ & 0,267 & $-0,711$ & 0,615 & 0,052 & $-0,537$ & $-0,271$ \\
\hline $\begin{array}{c}\text { Собственные } \\
\text { числа }\end{array}$ & 8,151 & 4,743 & 3,459 & 5,827 & 4,788 & 4,001 \\
\hline $\begin{array}{c}\text { Процент } \\
\text { дисперсии }\end{array}$ & 28,261 & 16,445 & 11,993 & 21,909 & 18,004 & 15,043 \\
\hline
\end{tabular}

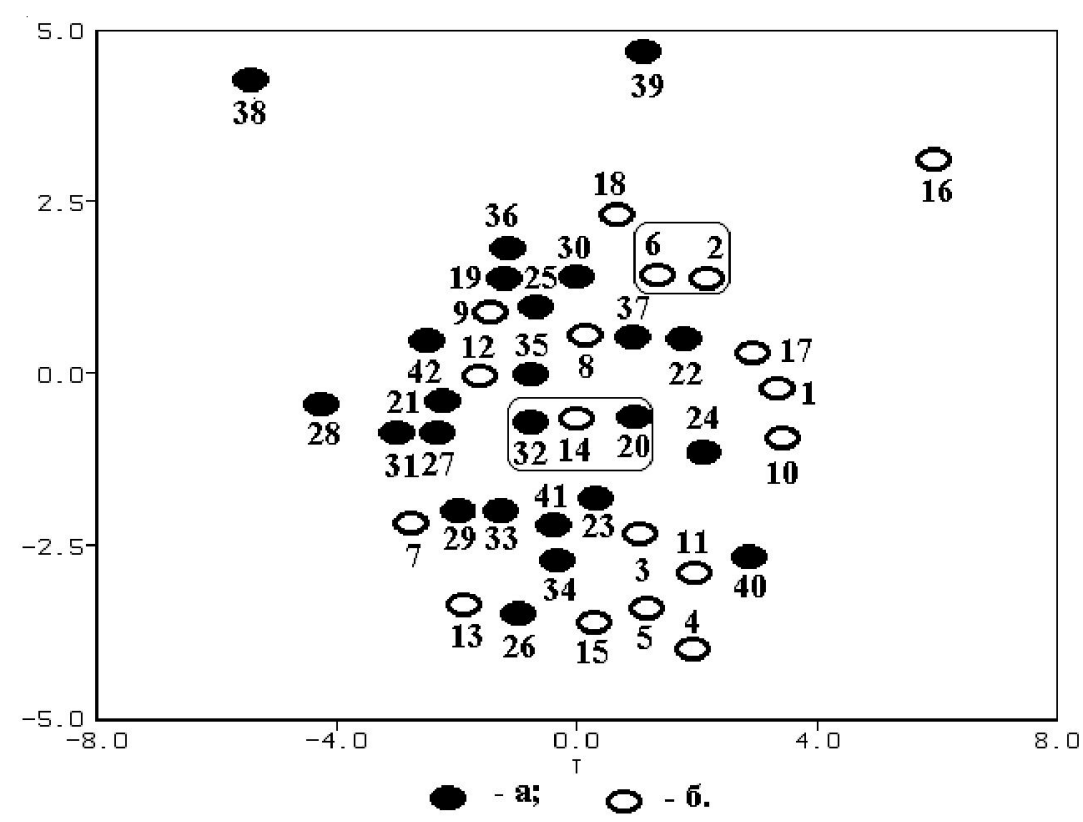

Рис. 1. Результат неметрического многомерного шкалирования и кластерного анализа расстояний близости по Махаланобису $\left(\mathrm{D}^{2}\right)$ между мужскими группами среднесарматского и раннесарматского времени:

$a$ - серии раннесарматского времени; $\sigma$ - серии среднесарматского времени

Серии среднесарматского времени: 1 - Терновский; 2 - Первомайский; 3 - Бережновка I; 4 - Кузин;

5 - Кривая Лука; 6 - Калиновка; 7 - Быково; 8 - Бережновка II; 9 - Старица; 10 - Канал Волга - Чограй; 11 - Жутово; 12 - Эвдык; 13 - Аккермень; 14 - Усть-Каменка; 15 - Новый; 16 - Колобовка; 17 - Перегрузное I; 18 - Аксай

Серии раннесарматского времени: 19 - Быково; 20 - Калиновка; 21 - Бережновка; 22 - Верхний Балыклей;

23 - Старица; 24 - Батаевка; 25 - Степной IV; 26 - Киляковка; 27 - Старые Киишки; 28 - Мечет Сай;

29 - Новый Кумак; 30 - Первомайский; 31 - Калмыково; 32 - Кара Оба; 33 - Эльтон; 34 - Кривая Лука; 35 - Верхнепогромное; 36 - Политотдельское; 37 - Перегрузное I; 38 - Колобовка; 39 - Маляевка; 40 - Новый; 41 - Аксай; 42 - Прохоровка

Fig. 1. The result of a non-metric multidimensional scaling and cluster analysis of the Mahalanobis distance $\left(D^{2}\right)$ of male groups of the Middle Sarmatian and Early Sarmatian time:

$a$ - series of the Early Sarmatian time; $b$ - series of the Middle Sarmatian time

Series of the Middle Sarmatian time: 1 - Ternovsky; 2 - Pervomaisky; 3 - Berezhnovka I; 4 - Kuzin; 5 - Krivaya Luka; 6 - Kalinovka; 7 - Bykovo; 8 - Berezhnovka II; 9 - Staritsa; 10 - Volga-Chogray Channel; 11 - Zhutovo; 12 - Evdyk; 13 - Akkermen; 14 - Ust-Kamenka; 15 - Novy; 16 - Kolobovka; 17 - Peregruznoe I; 18 - Aksai

Series of the Early Sarmatian time: 19 - Bykovo; 20 - Kalinovka; 21 - Berezhnovka; 22 - Verkhny Balykley; 23 - Staritsa;

24 - Bataevka; 25 - Stepnoy IV; 26 - Kilyakovka; 27 - Starye Kiishki; 28 - Mechet Say; 29 - Novy Kumak;

30 - Pervomaiskiy; 31 - Kalmykovo; 32 - Kara Oba; 33 - Elton; 34 - Krivaya Luka; 35 - Verkhnepogromnoe;

36 - Politotdelskoe; 37 - Peregruznoe I; 38 - Kolobovka; 39 - Malyaevka; 40 - Novy; 41 - Aksai; 42 - Prokhorovka 


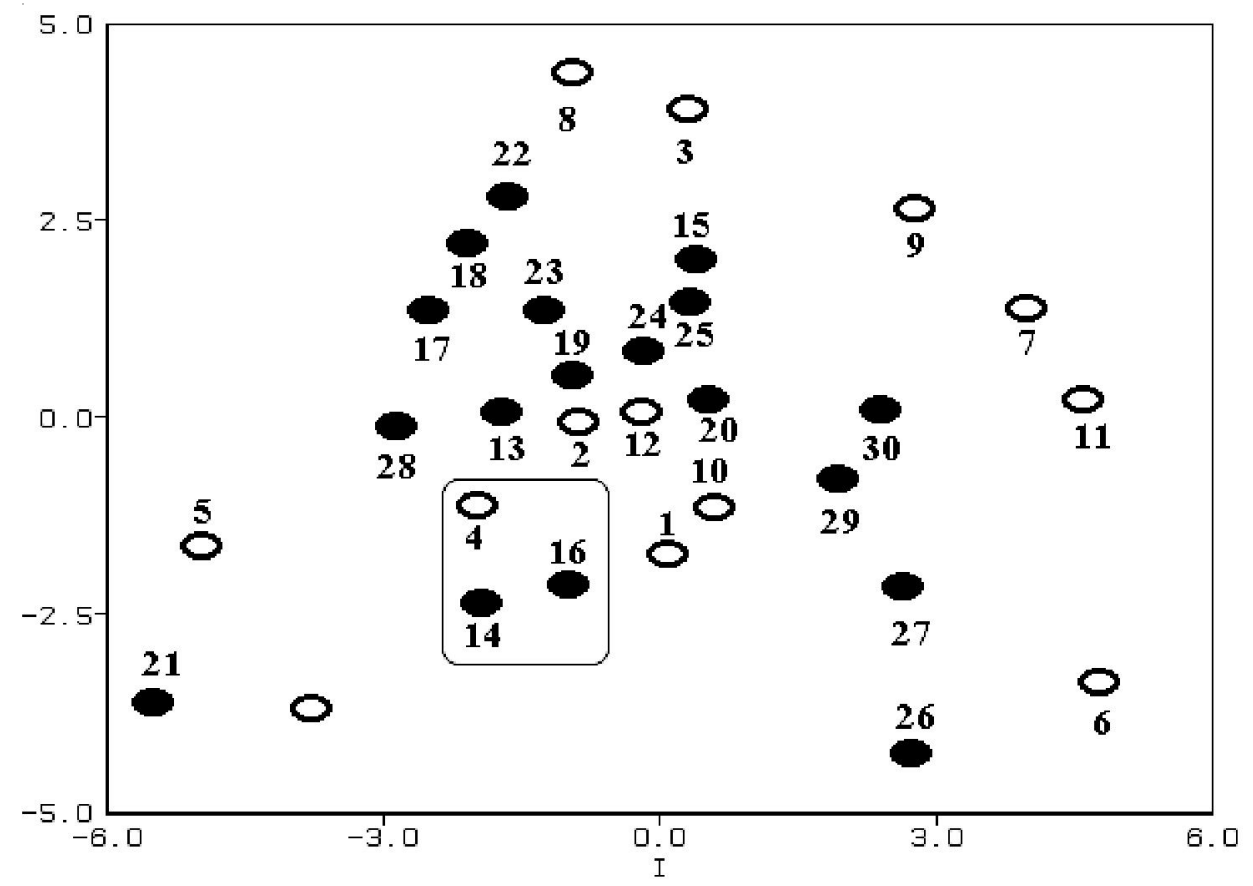

Рис. 2. Результат неметрического многомерного шкалирования и кластерного анализа расстояний близости по Махаланобису ( $\left.\mathrm{D}^{2}\right)$ между женскими группами среднесарматского и раннесарматского времени (обозначения на рис. 1 и 2 совпадают)

Серии среднесарматского времени: 1 - Бережновка I; 2 - Бережновка II; 3 - Калиновка; 4 - Крепь; 5 - Первомайский; 6 - Старица; 7 - Новый; 8 - Ново-Филипповка; 9 - Аккермень; 10 - Перегрузное I; 11 - Аксай; 12 - Терновский

Серии раннесарматского времени: 13 - Богодушанский Ерик; 14 - Первомайский; 15 - Старица; 16 - Калиновка; 17 - Бережновка II; 18 - Быково; 19 - Кривая Лука; 20 - Верхний Балыклей; 21 - Степной IV;

22 - Старые Киишки; 23 - Мечет Сай; 24 - Калмыково; 25 - Новый; 26 - Верхнепогромное; 27 - Красный Октябрь; 28 - Кардаилово; 29 - Царев; 30 - Перегрузное I

Fig. 2. The result of a non-metric multidimensional scaling and cluster analysis of the Mahalanobis distance $\left(\mathrm{D}^{2}\right)$ of female groups of the Middle Sarmatian and Early Sarmatian time (symbols in Fig. 1 and Fig. 2 coincide)

Series of the Middle Sarmatian time: 1 - Berezhnovka I; 2 - Berezhnovka II; 3 - Kalinovka; 4 - Krep; 5 - Pervomaisky; 6 - Staritsa; 7 - Novy; 8 - Novo-Filippovka; 9 - Akkermen; 10 - Peregruznoe I; 11 - Aksai; 12 - Ternovsky

Series of the Early Sarmatian time: 13 - Bogodushansky Erik; 14 - Pervomaisky; 15 - Staritsa; 16 - Kalinovka; 17 - Berezhnovka II; 18 - Bykovo; 19 - Krivaya Luka; 20 - Verkhny Balykley; 21 - Stepnoy IV; 22 - Starye Kiishki; 23 - Mechet Say; 24 - Kalmykovo; 25 - Novyy; 26 - Verkhnepogromnoe; 27 - Krasny Oktyabr; 28 - Kardailovo; 29 - Tsarev; 30 - Peregruznoe I 


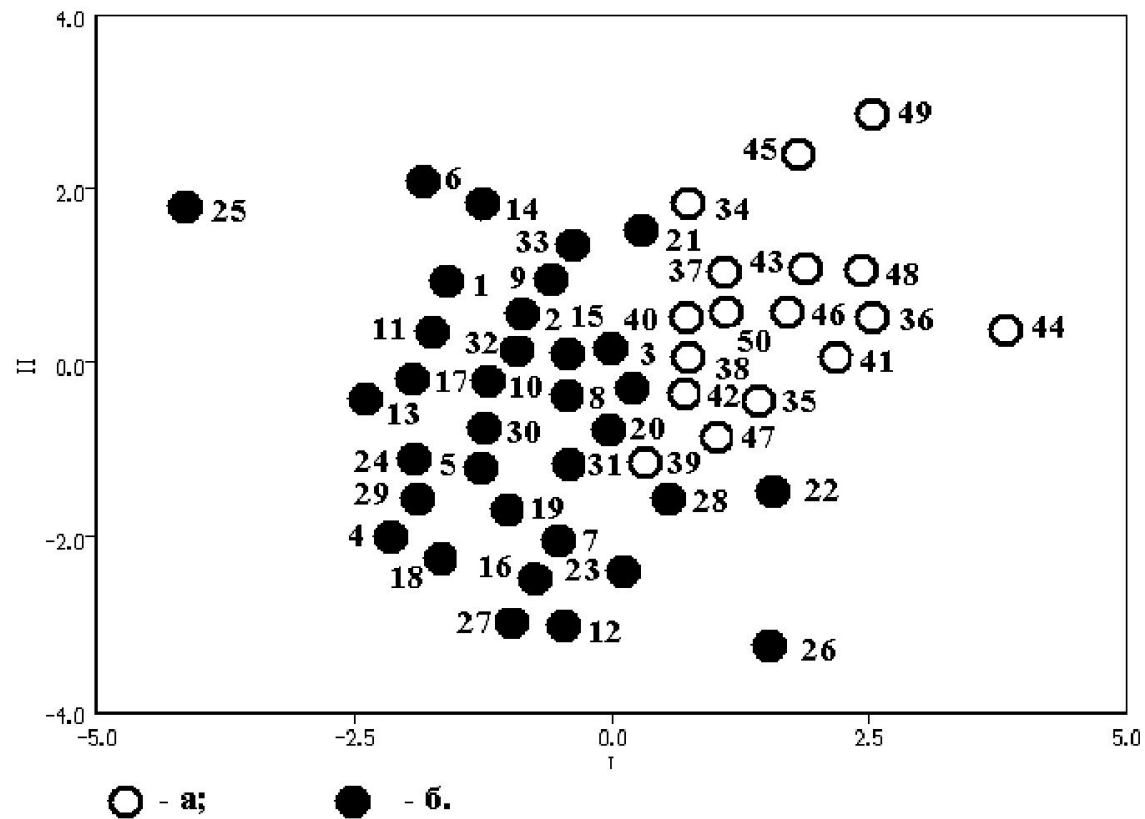

Рис. 3. Результат неметрического многомерного шкалирования расстояний близости по Махаланобису $\left(\mathrm{D}^{2}\right)$ мужских краниологических групп позднесарматского времени:

$a$ - серии без деформации; $\sigma$ - серии со следами искусственной деформации

Серии со следами искусственной деформации: 1 - Дюкер; 2 - Кермен Толга; 3 - Кузин; 4 - Абганерово II; 5 - Абганерово III; 6 - Абганерово IV; 7 - Джангр; 8 - Кривая Лука; 9 - Калиновка; 10 - Жутово; 11 - Старица;

12 - У-85; 13 - Купцын Толга; 14 - Архара; 15 - Хаар Нуурин Толга; 16 - Три Брата; 17 - Аксай;

18 - Новоаксайский; 19 - Громославка; 20 - Зергента; 21 - Ровное; 22 - Терновский; 23 - Степаневка;

24 - Авиловский; 25 -Петрунино; 26 - Костарево; 27 - Маляевка IV; 28 - Веселый; 29 - Ковыльнов III;

30 - Бережновка; 31 - Харьковка; 32 - Нижнедонская; 33 - Покровка-10

Серии без деформации: 34 - Кузин; 35 - Джангр; 36 - Кривая Лука; 37 - Старица; 38 - Бережновка;

39 - Бережновка II; 40 - Бережновка I; 41 - Калиновка; 42 - Купцын Толга; 43 - Канал Волга - Чограй; 44 - Цаган-Усн; 45 - Абганерово II; 46 - Терновский; 47 - Аксай; 48 - Перегрузное I;

49 - Первомайский; 50 - Нижнедонская

Fig. 3. The result of a non-metric multidimensional scaling of the Mahalanobis distance $\left(\mathrm{D}^{2}\right)$ of male craniological groups of the Late Sarmatian time:

$a$ - series without deformation; $b$ - series with traces of artificial deformation

Series with traces of artificial deformation: 1 - Dyuker; 2 - Kermen Tolga; 3 - Kuzin; 4 - Abganerovo II;

5 - Abganerovo III; 6 - Abganerovo IV; 7 - Dzhangr; 8 - Krivaya Luka; 9 - Kalinovka; 10 - Zhutovo; 11 - Staritsa;

12 - U-85; 13 - Kuptsyn Tolga; 14 - Arkhara; 15 - Khaar Nuurin Tolga; 16 - Tri Brata; 17 - Aksai; 18 - Novoaksaisky;

19 - Gromoslavka; 20 - Zergenta; 21 - Rovnoe; 22 - Ternovsky; 23 - Stepanevka; 24 - Avilovsky; 25 - Petrunino;

26 - Kostarevo; 27 - Malyaevka IV; 28 - Vesely; 29 - Kovylnov III; 30 - Berezhnovka; 31 - Kharkovka;

32 - Nizhnedonskaya; 33 - Pokrovka-10

Series without deformation: 34 - Kuzin; 35 - Dzhangr; 36 - Krivaya Luka; 37 - Staritsa; 38 - Berezhnovka; 39 - Berezhnovka II; 40 - Berezhnovka I; 41 - Kalinovka; 42 - Kuptsyn Tolga; 43 - Volga-Chogray Channel; 44 - Tsagan-Usn; 45 - Abganerovo II; 46 - Ternovsky; 47 - Aksai; 48 - Peregruznoe I;

49 - Pervomaisky; 50 - Nizhnedonskaya 


\section{ПРИМЕЧАНИЯ}

${ }^{1}$ Исследование выполнено при финансовой поддержке РФФИ и Администрации Волгоградской области, проект «Преемственность и трансформация в развитии культур раннего железного века Нижнего Поволжья по данным археологии, палеоантропологии, палеоэкологии и палеогенетики», № 17-11-34006.

2 Здесь и далее по тексту проценты даны на основе приведенных В.П. Шиловым данных [Шилов, 1959].

\section{СПИСОК ЛИТЕРАТУРЫ}

Абрамова М. П., 1993. Центральное Предкавказье в сарматское время (III в. до н. э. - IV в. н.э.) // Археология эпохи Великого переселения народов и раннего средневековья. Вып. 2. М. : ИА РАН : Institut für Ur- und Frühgeschichte der Universität Wien. 240 c.

Гинзбург В. В., 1959. Этногенетические связи древнего населения Сталинградского Заволжья (по материалам Калиновского могильника) // Материалы и исследования по археологии СССР. № 60. Т. І. М. : Изд-во АН СССР. С. 524-594.

Керефов Б. М., 1988. Памятники сарматского времени Кабардино-Балкарии. Нальчик : Эльбpyc. $216 \mathrm{c}$.

Клепиков В. М., Скрипкин А. С., 2002. Хронология раннесарматских памятников Нижнего Поволжья // Нижневолжский археологический вестник. Вып. 5. С. 47-81.

Кропотов В. В., 2010. Фибулы сарматской эпохи. Киев : Изд-во «АДЕФ-Украина». 384 с.

Малашев В. Ю., Яблонский Л. Т., 2008. Степное население Южного Приуралья в позднесарматское время. По материалам могильника Покровка 10. М. : Вост. лит. 365 с.

Марченко И. И., 1996. Сираки Кубани (по материалам курганных погребений Нижней Кубани). Краснодар : Изд-во КубГУ. 340 с.

Мошкова М. Г., 2000. Фибулы из позднесарматских погребений Южного Приуралья: вопросы хронологии и производства // Нижневолжский археологический вестник. Вып. 3. Волгоград. С. 186-200.

Рыков П. С., 1925. Сусловский курганный могильник // Ученые записки Саратовского государственного университета. Саратов : Изд-во СГУ. Т. 4. Вып. 2. С. 28-102.

Сергацков И. В., 2000. Сарматские курганы на Иловле. Волгоград : Изд-во ВолГУ. 396 с.

Сергацков И. В., 2002. Анализ сарматских погребальных памятников в I-II вв. н.э. // Статистическая обработка погребальных памятников
Азиатской Сарматии. Вып. III. Среднесарматская культура. М. : Вост. лит. С. 22-129.

Скрипкин А. С., 1977. Фибулы Нижнего Поволжья (по материалам сарматских погребений) // Советская археология. № 2. С. 100-120.

Скрипкин А. С., 1990а. О конечной дате раннесарматской культуры в Нижнем Поволжье // Вопросы археологии юга Восточной Европы. Элиста. С. 105-117.

Скрипкин А. С., 1990б. Азиатская Сарматия. Проблемы хронологии и ее исторический аспект. Саратов : Изд-во СГУ. 299 с.

Скрипкин А. С., 1997. Анализ сарматских погребальных памятников III-I вв. до н.э. // Статистическая обработка погребальных памятников Азиатской Сарматии. Вып. II. Раннесарматская культура (IV-I вв. до н.э.). М. С. 131-212.

Скрипкин А. С., 1998. Материалы Сусловского курганного могильника // Нижневолжский археологический вестник. Вып 1. С. 104-124.

Скрипкин А. С., 2005. Мечи и кинжалы с кольцевидным навершием // II Городцовские чтения. Материалы научной конференции, посвященной 100-летию деятельности В.А. Городцова в ГИМ. Апрель 2003 г. Тр. ГИМ. Вып. 145. М. С. 171-185.

Скрипкин А. С., 2014. О восточных связях сарматов II-I вв. до н.э. // Сарматы и внешний мир : материалы VIII Всерос. (с междунар. участием) науч. конф. «Проблемы сарматской археологии и истории». Уфимский археологический вестник. Вып. 14. Уфа : НИЯЛ УНЦ РАН, Центр «Наследие». С. 218-222.

Скрипкин А. С., 2015. Клинковое оружие в разработке хронологии и некоторых вопросов этнополитической истории раннесарматской культуры Волго-Уральского региона // Война и военное дело в скифо-сарматском мире : материалы Междунар. науч. конф., посвящ. памяти А.И. Мелюковой (Кагальник, 2629 апр. 2014 г.). Ростов н/Д : Изд-во ЮНЦРАН. C. $191-197$.

Скрипкин А. С., Минеева О. И., 2004. Об одном типе сарматских зеркал // Проблемы археологии Нижнего Поволжья : I Междунар. Нижневолж. археол. конф., 1-5 нояб. 2004 г. : тез. докл. Волгоград : Изд-во ВолГУ. С. 212-214.

Шилов В. П., 1959. Калиновский курганный могильник // Материалы и исследования по археологии СССР. № 60. Т. І. М. : Изд-во АН СССР. C. 323-523.

Raev B. A., 1994. Bronze Vessels of the La-Tene-Period Sarmatia // Akten der 10. Internationalen Tagung uber antiken Bronzen. Freiburg, 18-22 juli 1988, Stuttgart. S. 347-351. 


\section{REFERENCES}

Abramova M.P., 1993. Central Ciscaucasia in Sarmatian Time ( $3^{\text {rd }}$ Century B.C. $-4^{\text {th }}$ Century A.D.). Arkheologiya ehpokhi Velikogo pereseleniya narodov $i$ rannego srednevekovya, vol. 2. Moscow, IA RAN Publ. 240 p. (in Russian)

Ginzburg V.V., 1959. Ethnogenetic connections of the ancient population of the Stalingrad TransVolga region: (based on materials of the Kalinovskiy burial mound). Materialy $i$ issledovanija po arheologii SSSR, no. 60. Moscow, Publishing house of the Academy of Sciences of the USSR, pp. 524-594. (in Russian).

Kerefov B.M., 1988. Monuments of the Sarmatian time of Kabardino-Balkaria. Nalchik, Elbrus Publ. 216 p. (in Russian).

Klepikov V.M., Skripkin A.S., 2005. Chronology of the Early Sarmatian Monuments of the Lower Volga Region. The Lower Volga Archaeological Bulletin, vol. 5, pp. 47-81. (in Russian).

Kropotov V.V., 2010. Fibulas of the Sarmatian era. Kiev, ADEF-Ukraine Publ. 384 p. (in Russian).

Malashev V.Yu., Yablonsky L.T., 2008. The Steppe Population of the South Urals Area in the Late Sarmatian Time. According to the materials of the burial ground Pokrovka 10. Moscow, Vostochnaya literatura Publ. 365 p. (in Russian).

Marchenko I.I., 1996. Siraki of Kuban (based on the materials of the burial mounds of the Lower Kuban). Krasnodar, Publishing house of KubGU. 340 p. (in Russian).

Moshkova M.G., 2000. Fibulas from the Late Sarmatian burials of the Southern Urals: questions of chronology and production. The Lower Volga Archaeological Bulletin, vol. 3, pp. 186-200. (in Russian).

Rykov P.S., 1925. Suslovskiy burial ground. Uchenye zapiski Saratovskogo gosudarstvennogo universiteta. Saratov, Publishing house of Saratov State University, vol. 4, iss. 2, pp. 28102. (in Russian).

Sergatskov I.V., 2000. Sarmatian burial mounds on the Ilovlya river. Volgograd, Publishing house of Volgograd State University. (in Russian).

Sergatskov I.V., 2002. Analysis of Sarmatian funerary monuments I-II centuries AD. Statistical processing of funerary monuments of Asian Sarmatia. Iss. III. Middle Sarmatian culture. Moscow, Vostochnaya literatura Publ., pp. 22129. (in Russian).

Skripkin A.S., 1977. Fibulas of the Lower Volga region (based on the materials of Sarmatian burials). Sovetskaja arheologiya, no. 2, pp. 100-120. (in Russian).
Skripkin S.A., 1990a. About the final date of the Early Sarmatian culture in the Lower Volga region. Voprosy arheologii juga Vostochnoj Evropy. Elista, pp. 105-117. (in Russian).

Skripkin A.S., 1990b. Asian Sarmatia. Problems of chronology and its historical aspect. Saratov, Publishing house of Saratov State University. 299 p. (in Russian).

Skripkin A.S., 1997. Analysis of Sarmatian Burial Monuments of the $3^{\text {nd }}-1^{\text {st }}$ Centuries B.C. Statisticheskaya obrabotka pogrebalnykh pamyatnikov Aziatskoy Sarmatii. Vyp. II. Rannesarmatskaya kultura (IV-I vv. do n.e.). Moscow, pp. 131-212. (in Russian).

Skripkin A.S., 1998. Materials of Suslovskiy burial ground. The Lower Volga Archaeological Bulletin, vol. 1, pp. 104 -124. (in Russian).

Skripkin A.S., 2005. Swords and daggers with ring-shaped pommel. II Gorodcovskie chtenija. Materialy nauchnoj konferencii, posvjashhennoj 100-letiju dejatel'nosti V.A. Gorodcova v GIM. Aprel' $2003 \mathrm{~g}$. Proceedings of the GIM, vol. 145, pp. 171185. (in Russian).

Skripkin A.S., 2014. About the Eastern relations of the Sarmatians of the II-I centuries BC. Sarmaty $i$ vneshnij mir: materialy VIII Vseros. (s mezhdunar. uchastiem) nauch. konf. "Problemy sarmatskoj arheologii $i$ istorii». Ufimskij arheologicheskij vestnik, vol. 14. Ufa, NNS Research Institute of the Academy of Sciences of the Russian Academy of Sciences, Center «Nasledie», pp. 218-222. (in Russian).

Skripkin A.S., 2015. Blade weapons in the development of chronology and some issues of the ethnopolitical history of the Early Sarmatian culture of the Volga-Ural region. Vojna $i$ voennoe delo $v$ skifo-sarmatskom mire: materialy Mezhdunarodnoj nauchnoj konferencii, posvjashhennoj pamjati A.I. Meljukovoj (Kagal'nik, 26-29 apr. 2014 g.). Rostov-onDon, Publishing house of the Southern Scientific Centre of the RAS, pp. 191-197. (in Russian).

Skripkin A.S., Mineeva O.I., 2004. About one of the types of Sarmatian mirrors. Problemy arheologii Nizhnego Povolzh'ja: I Mezhdunar. Nizhnevolzh. arheol. konf., 1-5 nojab. 2004 g. Volgograd, Publishing house of Volgograd State University, pp. 212-214. (in Russian).

Shilov V.P., 1959. Kalinovskiy burial mound. Materialy i issledovanija po arheologii SSSR, no. 60. Moscow, Publishing house of the Academy of Sciences of the USSR, pp. 323-523. (in Russian).

Raev B.A., 1994. Bronze Vessels of the La-Tene-Period Sarmatia. Akten der 10. Internationalen Tagung uber antiken Bronzen. Freiburg, 1822 juli 1988. Stuttgart, pp. 347-351. 
M.A. Balabanova, A.S. Skripkin. On the Succession of Sarmatian Cultures and Population

\section{Information about the Authors}

Mariya A. Balabanova, Doctor of Sciences (History), Professor, Department of Russian and Foreign History, Archaeology, Volgograd State University, Prosp. Universitetsky, 100, 400062 Volgograd, Russian Federation, mary.balabanova@volsu.ru.

Anatoliy S. Skripkin, Doctor of Sciences (History), Professor, Department of Russian and Foreign History, Archaeology, Volgograd State University, Prosp. Universitetsky, 100, 400062 Volgograd, Russian Federation, anatoly.skripkin@volsu.ru, adsi@volsu.ru.

\section{Информация об авторах}

Мария Афанасьевна Балабанова, доктор исторических наук, профессор кафедры отечественной и зарубежной истории, археологии, Волгоградский государственный университет, просп. Университетский, 100, 400062 г. Волгоград, Российская Федерация, mary.balabanova@volsu.ru.

Анатолий Степанович Скрипкин, доктор исторических наук, профессор кафедры отечественной и всеобщей истории, археологии, Волгоградский государственный университет, просп. Университетский, 100, 400062 г. Волгоград, Российская Федерация, anatoly.skripkin@volsu.ru, adsi@volsu.ru. 